\title{
BIOACTIVITY SCREENING OF SELECTED TRADITIONAL MEDICINAL PLANTS OF KERALA
}

\author{
ALBY ALPHONS BABY ${ }^{1,2 *}$, REGI RAPHAEL $\mathrm{K}^{1,2}$ \\ ${ }^{1}$ Research and Development Centre, Bharathiar University, Coimbatore, Tamil Nadu, India. ${ }^{2}$ Department of Botany, St. Mary's College, \\ Thrissur, Kerala, India. Email: albyalphons@gmail.com
}

Received: 23 June 2018, Revised and Accepted: 07 August 2018

ABSTRACT

Objectives: Traditional medicines all over the world is revaluing nowadays by extensive research programs. To validate the traditional use, the active components in them need to be identified, characterized, and biologically evaluated. Stereospermum suaveolens, Hygrophila spinosa, and Naravelia zeylanica are important medicinal plants used by the ethnic people of Kerala against various ailments. The present study validates the ethnomedical uses of S. suaveolens, H. spinosa, and N. zeylanica by screening their antimicrobial, anthelmintic, and antioxidant properties.

Method: All the analyses were done according to standard protocols.

Results: The ethanolic extracts of their useful parts were investigated for antimicrobial activity against 10 human pathogenic microorganisms. All the three plants had shown prominent antimicrobial activities, and $S$. suaveolens exhibits comparatively more antifungal activity in their higher concentration $(500 \mu \mathrm{g} / \mathrm{mL})$. Anthelmintic efficiency of the plants was screened using Indian adult earthworm Pheretima posthuma. All of them had shown significant activity, and the highest was observed in $S$. suaveolens leaves. Antioxidant potential of the plants was screened using 2,2 diphenyl 1-picrylhydrazyl (DPPH) free radical scavenging assay and superoxide anion scavenging assay. In DPPH free radical scavenging assay, maximum radical scavenging was shown by $S$. suaveolens with IC50 value $61.6 \pm 2.3 \mu \mathrm{g} / \mathrm{mL}$, and in superoxide anion scavenging assay, maximum activity was in N. zeylanica with IC50 value of $74.66 \pm 8.5 \mu \mathrm{g} / \mathrm{mL}$.

Conclusion: This study provides scientific evidence on the traditional use of S. suaveolens (leaves), H. spinosa (leaves), and $N$. zeylanica (aerial part) in treating microbial diseases, worm disturbances, and their potential as an antioxidant agent.

Keywords: Stereospermum suaveolens, Hygrophila spinosa, Naravelia zeylanica, Antimicrobial, Anthelmintic, Antioxidant, Traditional medicine.

(C) 2018 The Authors. Published by Innovare Academic Sciences Pvt Ltd. This is an open access article under the CC BY license (http://creativecommons. org/licenses/by/4. 0/) DOI: http://dx.doi.org/10.22159/ajpcr.2018.v11i12.28070

\section{INTRODUCTION}

Ayurvedic system, tribal medicine, and folk medicines are the three plants based on healing systems in Kerala. Ayurvedic system possesses a very good written documents and history. Tribal medicine is the medicinal knowledge of forest-dwelling tribals, which is not having any documentation and procedure. Folk medicine is the orally transmitting knowledge on medicinal plants for the primary health care [1]. The wide acceptance of traditional medicine as an alternative form of health care and the alarming increase in the incidence of new and reemerging infectious diseases bring about the necessity to investigate these medicinal plants. Medicinal values of various plants are due to the presence of various bioactive compounds such as phenolic compounds, alkaloids, flavonoids, and tannins that produce definite physiological action in the human body [2].

Stereospermum suaveolens DC is a medicinal tree species native to India, Bangladesh, and Myanmar. The Bignoniaceae family having about 100 genera with 800 species is known for their antimicrobial and antiprotozoal properties [3].

Naravalia zeylanica DC belonging to the family Ranunculaceae is a woody climber in habit with tuberous roots, opposite and cordate leaflets, and flowers are small and arranged in panicles. Red-colored achenes with long feathery styles occur in the hot to warm regions in India [4]. The plant is traditionally used by the healers to treat pitta, vitiated vata, inflammations, skin diseases, headache, arthritis, colic, wounds, and ulcers [5]. Leaf paste is consumed to treat chest pain. The vines when crushed give a pungent odor which is inhaled to cure a cold and all types of headaches including migraine [6].
Hygrophila spinosa Anders belongs to the family Acanthaceae. The parts of this plant are widely used in traditional medicine for the treatment of various disorders, which include anasarca, diseases of the urinogenital tract, dropsy from chronic Bright's disease, hyperdipsia, vesical calculi, flatulence, diarrhea, dysentery, leukorrhea, gonorrhea, asthma, blood diseases, gastric diseases, inflammation, cancer, rheumatism, painful micturition, and menorrhagia [7-10].

Thus, this study aimed to evaluate the potential antimicrobial, anthelmintic, and antioxidant properties of $S$. suaveolens leaves, $H$. spinosa leaves, and N. zeylanica aerial part and to provide scientific evidence for its folk claim.

\section{METHODS}

Collection of plant material and preparation of the extract The fresh leaves of $S$. suaveolens and $H$. spinosa and aerial parts of $N$. zeylanica were collected in March 2014 from Mannamangalam village of Thrissur District and shade dried for several days. The coarse powder of the dried plant materials was prepared, and $50 \mathrm{~g}$ of the powder was soaked in $95 \%$ ethanol (1:5) for $72 \mathrm{~h}$. Using a rotary evaporator, the solvents were removed. For the future studies, the concentrated extracts were refrigerated [11].

\section{Antimicrobial assay}

Organisms and culture media

The microorganisms for the antimicrobial screening were collected from the Microbiology Laboratory, St. Mary's College, Thrissur. The pathogenic organisms used were Bacillus cereus, Staphylococcus aureus, Streptococcus pyogenes, Klebsiella pneumoniae, Salmonella 
typhi, Pseudomonas aeruginosa, Candida albicans, Aspergillus niger, and Penicillium notatum. Nutrient agar (NA) was used to maintain bacterial cultures, and fungal cultures were maintained on Sabouraud Dextrose Agar (SDA).

\section{Antibacterial and antifungal activity of the plant extract}

Well diffusion assay [12] on NA and SDA plates was used to determine the antibacterial and antifungal properties, respectively. To prepare the microbial suspension, bacteria inoculated into nutrient broth (NB) and fungus into Sabouraud dextrose broth (SDB) and incubated at $37^{\circ} \mathrm{C}$ for $6 \mathrm{~h}$. The transmittance of the resulting suspension was diluted using NB and SDB for getting the value 74.3\% (absorbance of 0.132 ) at $600 \mathrm{~nm}$. This percentage is comparable to $0.5 \mathrm{McFarland}$ turbidity standards. This level of turbidity is equivalent to approximately $1.5 \times 10^{8} \mathrm{CFU} / \mathrm{mL}$ [13]. On the surface of NA plates, bacterial cultures were inoculated and fungal cultures were inoculated on SDA plates. Subsequently, wells with a diameter of $6 \mathrm{~mm}$ were prepared on NA and SDA plates using sterile cork borer, and $25 \mu \mathrm{L}$ of sample in different concentrations $(100 \mu \mathrm{g} / \mathrm{mL}, 250 \mu \mathrm{g} / \mathrm{mL}$, and $500 \mu \mathrm{g} / \mathrm{mL})$ was loaded in each well. Antibiotics were used as positive control (chloramphenicol for bacteria and fluconazole for fungus) [14]. The tests were carried out in triplicates. The plates were incubated at $37^{\circ} \mathrm{C}$ for $24 \mathrm{~h}$. Zone of clearing was measured at the end of the incubation period using a transparent ruler. Zones of inhibition $>6 \mathrm{~mm}$ were taken as susceptible to the extracts.

\section{Anthelmintic property}

The standard albendazole $(25 \mathrm{mg} / \mathrm{mL})$ and the test solutions of S. suaveolens, H. spinosa, and N. zeylanica $(25,50$, and $100 \mathrm{mg} / \mathrm{mL})$ were evaluated for anthelmintic activity with Indian adult earthworm P. posthuma. Time taken for paralysis and time of death of each worm were observed for $4 \mathrm{~h}$. Time of paralysis was noted when the worms did not show any signs of movement. Death of each worm was confirmed by vigorous shaking and by dipping in warm water of $50^{\circ} \mathrm{C}[15]$

\section{Antioxidant property screening}

\section{2,2 Diphenyl 1-picrylhydrazyl (DPPH) radical scavenging assay}

Free radical scavenging activity of the plant extracts was assessed on the basis of the radical scavenging effect of the stable DPPH, by a modified method [16]. The diluted working solutions of the test extracts $(10-1000 \mu \mathrm{g} / \mathrm{mL}$ concentration) and $6.34 \mu \mathrm{M}$ solution of DPPH were prepared in methanol, and $100 \mu \mathrm{L}$ of drug to be tested, $100 \mu \mathrm{L} \mathrm{DPPH}$ solution, and $800 \mu \mathrm{L}$ of methanol were taken in a test tube and mixed well. These solution mixtures were incubated in the dark for $20 \mathrm{~min}$. Optical density was measured after incubation at 517 $\mathrm{nm}$ using Cecil-elect spectrophotometer. Methanol $(900 \mu \mathrm{L})$ with DPPH solution $(6.34 \mu \mathrm{M}, 100 \mu \mathrm{L})$ was taken as control and methanol as blank. The optical density was recorded, and to calculate the percentage of inhibition, the following formula was used:

Percent (\%) inhibition of DPPH activity $=$ A-B $/ \mathrm{A} \times 100$

Where A = optical density of the control and B = optical density of the sample.

\section{Super oxide radical scavenging assay}

In vitro superoxide radical scavenging activity was measured by NBT reduction method [17]. In the presence of light, riboflavin undergoes auto-oxidation and forms superoxide radicals, and it reduces NBT to a blue-colored formazan which can be measured at $590 \mathrm{~nm}$.

$200 \mu \mathrm{L}$ EDTA, $100 \mu \mathrm{L}$ riboflavin solution, $200 \mu \mathrm{L}$ ethanol, and $100 \mu \mathrm{L}$ NBT solution were mixed in a test tube and made up to $3 \mathrm{~mL}$ using phosphate buffer. The solution was incubated in light for $15 \mathrm{~min}$, and the absorbance of the resulting solution was measured at $590 \mathrm{~nm}$ using phosphate buffer as blank. This was taken as control reading. For screening of test sample, along with the above solutions, added $100 \mu \mathrm{L}$ sample of varying concentrations $(10-1000 \mu \mathrm{g} / \mathrm{mL})$, and finally, the volume was made up to $3 \mathrm{~mL}$ using phosphate buffer and the reading was taken after 15 min of illumination. The formula given below was used to find out the percentage of inhibition:

Percent $(\%)$ inhibition $=\mathrm{A}-\mathrm{B} / \mathrm{A} \times 100$

Where $\mathrm{A}=$ optical density of the control and $\mathrm{B}=$ optical density of the sample.

\section{RESULTS AND DISCUSSION}

\section{Antimicrobial screening}

The results of the study showed that the ethanolic extracts of $S$. suaveolens leaves, $H$. spinosa leaves, and aerial parts of $N$. zeylanica had prominent antimicrobial activity against the human pathogenic bacteria and fungi studied [Tables 1-6]. All the medicinal plants screened were effective against all the bacterial and fungal species studied, while $S$. suaveolens shows more prominent antifungal activity with maximum zone of growth inhibition against Aspergillus flavus and C. albicans $(23.3 \pm 0.57 \mathrm{~mm}$ and $23.6 \pm 0.57 \mathrm{~mm}$ at $500 \mu \mathrm{g} / \mathrm{mL}$ concentration). C. albicans was resistant to fluconazole, but it showed promising activity with plant extracts, and the maximum zone of inhibition against C. albicans was observed in $N$. zeylanica $(24 \pm 1 \mathrm{~mm}$ at $500 \mu \mathrm{g} / \mathrm{mL})$.

Table 1: Antibacterial property of S. suaveolens leaves

\begin{tabular}{|c|c|c|c|c|}
\hline \multirow[t]{2}{*}{ Organism } & \multicolumn{4}{|l|}{ Zone of inhibition } \\
\hline & $\begin{array}{l}\text { Chloramphenicol } \\
(25 \mu \mathrm{g})\end{array}$ & $100 \mu \mathrm{g}$ & $250 \mu \mathrm{g}$ & $500 \mu \mathrm{g}$ \\
\hline K. pn & $25 \pm 1$ & $7.3 \pm 0.1 .15$ & $9.6 \pm 0.57$ & $11.3 \pm 1.15$ \\
\hline S. typhi & $23.6 \pm 0.57$ & $9.6 \pm 0.57$ & $13 \pm 1$ & $16.6 \pm 0.57$ \\
\hline P. aeruginosa & $11.6 \pm 0.57$ & $6.6 \pm 0.57$ & $8.6 \pm 0.57$ & $10.6 \pm 1.15$ \\
\hline B. cereus & $20.6 \pm 0.57$ & $7.3 \pm 1.15$ & $11 \pm 1$ & $12.6 \pm 1.15$ \\
\hline S. pyogenes & $18.6 \pm 1.15$ & $6.6 \pm 1.15$ & $9.6 \pm 0.57$ & $12.3 \pm 0.57$ \\
\hline S. aureus & $23.3 \pm 0.57$ & $7.6 \pm 0.57$ & $10 \pm 1$ & $12.6 \pm 1.15$ \\
\hline
\end{tabular}

S. suaveolens: Stereospermum suaveolens, K. pneumoniae: Klebsiella

pneumoniae, S. typhi: Salmonella typhi, P. aeruginosa: Pseudomonas aeruginosa,

B. cereus: Bacillus cereus, S. pyogenes: Streptococcus pyogenes, S. aureus:

Staphylococcus aureus

Table 2: Antifungal property of $S$. suaveolens leaves

\begin{tabular}{|c|c|c|c|c|}
\hline \multirow[t]{2}{*}{ Organism } & \multicolumn{4}{|c|}{ Zone of inhibition (mm) } \\
\hline & $\begin{array}{l}\text { Fluconazole } \\
(15 \mu \mathrm{g})\end{array}$ & $100 \mu \mathrm{g}$ & $250 \mu \mathrm{g}$ & $500 \mu \mathrm{g}$ \\
\hline A. niger & $12.7 \pm 1.15$ & $15.3 \pm 0.57$ & $19.6 \pm 0.57$ & $21 \pm 1$ \\
\hline A. flavus & $13.7 \pm 1.15$ & $16.7 \pm 1.151 .2$ & $20.7 \pm 0.57$ & $23.3 \pm 0.57$ \\
\hline P. notatum & $9.3 \pm 0.57$ & $11.6 \pm 0.57$ & $13.7 \pm 1.15$ & $18.6 \pm 0.57$ \\
\hline C. albicans & $\mathrm{R}$ & $17.3 \pm 0.57$ & $20.6 \pm 0.58$ & $23.6 \pm 0.57$ \\
\hline
\end{tabular}

R: Resistant. S. suaveolens: Stereospermum suaveolens, A. niger: Aspergillus niger, A. flavus: Aspergillus flavus, P. notatum: Penicillium notatum, C. albicans: Candida albicans

Table 3: Antibacterial property of $\boldsymbol{H}$. spinosa leaves

\begin{tabular}{|c|c|c|c|c|}
\hline \multirow[t]{2}{*}{ Organism } & \multicolumn{4}{|l|}{ Zone of inhibition } \\
\hline & $\begin{array}{l}\text { Chloramphenicol } \\
(25 \mu \mathrm{g})\end{array}$ & $100 \mu \mathrm{g}$ & $250 \mu \mathrm{g}$ & $500 \mu \mathrm{g}$ \\
\hline K. pn & $24.7 \pm 1.15$ & $8.6 \pm 1.15$ & $10.3 \pm 1.15$ & $13.3 \pm$ \\
\hline S. typhi & $20.3 \pm 0.57$ & $6.3 \pm 0.57$ & $9.6 \pm 1.15$ & $12.3 \pm 0.57$ \\
\hline P. aeruginosa & $13 \pm 0.83$ & $7.6 \pm 0.57$ & $9.6 \pm 1.15$ & $14 \pm 1$ \\
\hline B. cereus & $29 \pm 0.93$ & $8.3 \pm 0.57$ & $10.3 \pm 1.15$ & $14.3 \pm 0.57$ \\
\hline S. pyogenes & $17.6 \pm 2.5$ & $7.7 \pm 0.57$ & $11.6 \pm 1.2$ & $13.6 \pm 0.57$ \\
\hline S. aureus & $24 \pm 1.7$ & $7.6 \pm 0.57$ & $9.3 \pm 0.57$ & $12.5 \pm 1.52$ \\
\hline
\end{tabular}

H. spinosa: Hygrophila spinosa, K. pneumoniae: Klebsiella pneumoniae,

S. typhi: Salmonella typhi, P. aeruginosa: Pseudomonas aeruginosa,

B. cereus: Bacillus cereus, S. pyogenes: Streptococcus pyogenes,

S. aureus: Staphylococcus aureus 
Table 4: Antifungal property of $H$. spinosa leaves

\begin{tabular}{lllll}
\hline Organism & \multicolumn{4}{l}{ Zone of inhibition $(\mathbf{m m})$} \\
\cline { 2 - 5 } & $\begin{array}{l}\text { Fluconazole } \\
\mathbf{( 1 5} \boldsymbol{\mu g})\end{array}$ & $\mathbf{1 0 0} \boldsymbol{\mu g}$ & $\mathbf{2 5 0} \mathbf{~ g}$ & $\mathbf{5 0 0} \mathbf{~ g}$ \\
\hline A. niger & $7.6 \pm 0.57$ & $8.3 \pm 0.57$ & $11.7 \pm 1.15$ & $15.3 \pm 0.57$ \\
A. flavus & $7.6 \pm 0.57$ & $9.6 \pm 0.57$ & $12.6 \pm 1.15$ & $14.3 \pm 0.57$ \\
P. notatum & $7.6 \pm 0.57$ & $8.3 \pm 0.57$ & $9.6 \pm 0.57$ & $12.6 \pm 1.15$ \\
C. albicans & $\mathrm{R}$ & $9.7 \pm 1.15$ & $14.3 \pm 0.58$ & $16.6 \pm 0.57$ \\
\hline
\end{tabular}

H. spinosa: Hygrophila spinosa, A. niger: Aspergillus niger, A. flavus: Aspergillus flavus, $P$. notatum: Penicillium notatum, C. albicans: Candida albicans

Table 5: Antibacterial property of $N$. zeylanica areal part

\begin{tabular}{|c|c|c|c|c|}
\hline \multirow[t]{2}{*}{ Organism } & \multicolumn{4}{|l|}{ Zone of inhibition } \\
\hline & $\begin{array}{l}\text { Chloramphenicol } \\
(25 \mu \mathrm{g})\end{array}$ & $100 \mu \mathrm{g}$ & $250 \mu \mathrm{g}$ & $500 \mu \mathrm{g}$ \\
\hline K.p & $18.7 \pm 1$. & $7.6 \pm 1.2$ & $9.6 \pm 0.57$ & $11.7 \pm 1.2$ \\
\hline S. typhi & $16.6 \pm 0.57$ & $7.7 \pm 1.15$ & $9.7 \pm 1.15$ & $12.6 \pm 0.57$ \\
\hline P. aeruginosa & $9.3 \pm 1.2$ & $7.6 \pm 0.57$ & $10.6 \pm 0.57$ & $13.4 \pm 0.92$ \\
\hline B. cereus & $16.7 \pm 1.15$ & $8.7 \pm 1.15$ & $11.6 \pm 0.57$ & $13.3 \pm 0.57$ \\
\hline S. pyogenes & $17.6 \pm 2.5$ & $8.7 \pm 0.57$ & $10.6 \pm 1.2$ & $12 \pm 0.57$ \\
\hline S. aureus & $14.6 \pm 0.72$ & $9.6 \pm 0.57$ & $12.6 \pm 0.57$ & $14.2 \pm 0.57$ \\
\hline
\end{tabular}

N. zeylanica: Naravelia zeylanica, K. pneumoniae: Klebsiella pneumoniae, S. typhi: Salmonella typhi, P. aeruginosa: Pseudomonas aeruginosa, B. cereus: Bacillus cereus, S. pyogenes: Streptococcus pyogenes, S. aureus: Staphylococcus aureus

Table 6: Antifungal property of $N$. zeyanica areal part

\begin{tabular}{lllll}
\hline Organism & \multicolumn{4}{l}{ Zone of inhibition (mm) } \\
\cline { 2 - 5 } & $\begin{array}{l}\text { Fluconazole } \\
(\mathbf{1 5} \boldsymbol{\mu g})\end{array}$ & $\mathbf{1 0 0} \boldsymbol{\mu g}$ & $\mathbf{2 5 0} \boldsymbol{\mu g}$ & $\mathbf{5 0 0} \boldsymbol{\mu g}$ \\
\hline A. niger & $12.5 \pm 0.76$ & $16.6 \pm 2.5$ & $23.3 \pm 1.15$ & $23.4 \pm 1.15$ \\
A. flavus & $14.3 \pm 0.64$ & $11 \pm 1$ & $12.6 \pm 1.15$ & $18.6 \pm 1.15$ \\
P. notatum & $8.6 \pm 0.57$ & $14.6 \pm 1.15$ & $17.6 \pm 1.15$ & $19.3 \pm 0.57$ \\
C. albicans & $\mathrm{R}$ & $18.6 \pm 0.57$ & $21.6 \pm 0.58$ & $24 \pm 1$ \\
\hline
\end{tabular}

N. zeylanica: Naravelia zeylanica, A. niger: Aspergillus niger, A. flavus: Aspergillus flavus, P. notatum: Penicillium notatum, C. albicans: Candida albicans
Due to the reported development of resistance by bacteria and fungi to various commercially available antimicrobial agents, the plant extracts are potential sources of new compounds, which may be developed as effective drugs against the infectious microorganisms. Further, the use of these plants may offer a new source of antifungal agent against the pathogenic fungus such as $C$. albicans which inhibited by the crude drugs in dose-dependent manner.

\section{Anthelmintic property screening}

It was seen that the ethanolic extracts of leaves of $S$. suaveolens and $H$. spinosa and aerial parts of $N$. zeylanica possess dose-dependent antihelmintic activity when compared to a standard drug albendazole. The mean paralyzing time of P. posthuma with the dose of $25 \mathrm{mg} / \mathrm{mL}$ concentration in $S$. suaveolens, $H$. hygrophilla, and N. zeylanica was found to be $38 \pm 1.53,119.7 \pm 3.5$, and $35 \pm 2.3 \mathrm{~min}$, respectively, and the mean death time of $P$. posthuma with the dose of $25 \mathrm{mg} / \mathrm{mL}$ of plant extracts was $78.6 \pm 2.3,119.7 \pm 3.5$, and $35 \pm 2.3 \mathrm{~min}$. All the three plants possess significant activity, and among them, $N$. zeylanica shows the highest activity by causing paralysis and mortality within minimum time. Albendazole, the commercially used anthelmintic drug at a dose of $25 \mathrm{mg} / \mathrm{mL}$, causes only paralysis, and no death was observed during the experimental period of $4 \mathrm{~h}$ [Tables 7-9].

\section{Antioxidant property screening}

The action of antioxidant compounds may be an initiator of the complexes of pro-oxidant metals, free radical scavengers, reducing agents, and quenchers of singlet oxygen formation [18]. Therefore, the importance of search for natural antioxidants has increased in the recent years, so many researchers focused on the same [19].

\section{DPPH radical scavenging assay}

In many disorders like cancer, neurodegenerative diseases, and AIDSfree radicals are playing important role [20]. For the management of these diseases, antioxidants are playing a vital role due to their radical scavenging activity. DPPH stable free radical method is a sensitive way to determine the antioxidant activity of plant extracts [20]. By measuring the decrease in the absorbance at $517 \mathrm{~nm}$, the reduction capacity of DPPH radicals by the antioxidants can be measured. The percentage of DPPH radical scavenging activity of the ethanolic extracts of S. suaveolens, H. spinosa, and N. zeylanica is presented in Tables 10-12, and they shows prominent activity with IC50 values $61.6 \pm 2.3,67.5 \pm 3.5$, and $373 \pm 2.81$, respectively. S. suaveolens is more promising among them with least IC50 value.

Table 7: Anthelmintic property of S. suaveolens leaves

\begin{tabular}{llllll}
\hline Observation & $\begin{array}{l}\text { Distilled } \\
\text { water }\end{array}$ & $\begin{array}{l}\text { Albendazole } \\
\mathbf{( 2 5} \mathbf{~ m g / m L )}\end{array}$ & $\begin{array}{l}\text { Drug } \\
\mathbf{( 2 5} \mathbf{~ m g} / \mathbf{m L})\end{array}$ & $\begin{array}{l}\text { Drug } \\
\mathbf{( 5 0} \\
\mathbf{m g m L}\end{array}$ & $\begin{array}{l}\text { Drug } \\
\mathbf{( 1 0 0} \mathbf{~ m g m L})\end{array}$ \\
\hline Time taken for paralysis (min) & - & $27 \pm 0.72$ & $38 \pm 1.53$ & $25.7 \pm 2.08$ & $13 \pm 1.19$ \\
Time taken for death (min) & - & - & $78.6 \pm 2.3$ & $63.3 \pm 2.5$ & $27.3 \pm 2.08$ \\
\hline
\end{tabular}

S. suaveolens: Stereospermum suaveolens

Table 8: Anthelmintic property of $H$. spinosa leaves

\begin{tabular}{llllll}
\hline Observation & $\begin{array}{l}\text { Distilled } \\
\text { water }\end{array}$ & $\begin{array}{l}\text { Albendazole } \\
\mathbf{( 2 5} \mathbf{~ m g / m L )}\end{array}$ & $\begin{array}{l}\text { Drug } \\
\mathbf{( 2 5} \mathbf{~ m g} / \mathbf{m L})\end{array}$ & $\begin{array}{l}\text { Drug } \\
\mathbf{( 5 0} \mathbf{~ m g} / \mathbf{m L})\end{array}$ & $\begin{array}{l}\text { Drug } \\
\mathbf{( 1 0 0} \mathbf{~ m g} / \mathbf{m L})\end{array}$ \\
\hline Time taken for paralysis (min) & - & $32.4 \pm 2$ & $56.3 \pm 0.57$ & $32.7 \pm 3.21$ & $24 \pm 1.73$ \\
Time taken for death (min) & - & - & $119.7 \pm 3.5$ & $53 \pm 2$ & $43.7 \pm 1.53$ \\
\hline
\end{tabular}

Table 9: Anthelmintic property of $N$. zeylanica aerial part

\begin{tabular}{|c|c|c|c|c|c|}
\hline Observation & $\begin{array}{l}\text { Distilled } \\
\text { water }\end{array}$ & $\begin{array}{l}\text { Albendazole } \\
(25 \mathrm{mg} / \mathrm{mL})\end{array}$ & $\begin{array}{l}\text { Drug } \\
(25 \mathrm{mg} / \mathrm{mL})\end{array}$ & $\begin{array}{l}\text { Drug } \\
(50 \mathrm{mg} / \mathrm{mL})\end{array}$ & $\begin{array}{l}\text { Drug } \\
(100 \mathrm{mg} / \mathrm{mL})\end{array}$ \\
\hline Time taken for paralysis (min) & - & $29 \pm 2$ & $28 \pm 1.5$ & $21 \pm 2$ & $16 \pm 3$ \\
\hline Time taken for death (min) & - & - & $35 \pm 2.3$ & $31 \pm 2.6$ & $21 \pm 2$ \\
\hline
\end{tabular}

N. zeylanica: Naravelia zeylanica 
Table 10: Antioxidant property of $S$. suaveolens leaves

\begin{tabular}{lll}
\hline $\begin{array}{l}\text { Concentration of plant } \\
\text { extract }(\boldsymbol{\mu g} / \mathrm{L})\end{array}$ & \multicolumn{2}{l}{ Percentage of inhibition } \\
\cline { 2 - 3 } & DPPH & NBT \\
\hline 10 & $14.47 \pm 1$ & $15.07 \pm 1.51$ \\
15 & $17.48 \pm 0.92$ & $31.5 \pm 2.12$ \\
25 & $35.05 \pm 0.90$ & $34.37 \pm 1.27$ \\
50 & $42.02 \pm 2.68$ & $38.11 \pm 1.1$ \\
75 & $60.65 \pm 3.85$ & $42.16 \pm 1.18$ \\
100 & $88.16 \pm 2.91$ & $46.93 \pm 1$ \\
250 & $91.07 \pm 0.25$ & $58.16 \pm 1.10$ \\
500 & $90.20 \pm 0.20$ & $69.53 \pm 1.47$ \\
750 & $93.27 \pm 0.25$ & $77.9 \pm 0.75$ \\
1000 & $94.44 \pm 0.15$ & $79.9 \pm 0.45$ \\
IC 50 value & $61.6 \pm 2.3$ & $146.6 \pm 3.6$ \\
\hline
\end{tabular}

DPPH: 2,2 Diphenyl 1-picrylhydrazyl, S. suaveolens: Stereospermum suaveolens

Table 11: Antioxidant property of $H$. spinosa leaves

\begin{tabular}{lll}
\hline $\begin{array}{l}\text { Concentration of plant } \\
\text { extract }(\mu \mathrm{g} / \mathrm{L})\end{array}$ & \multicolumn{2}{l}{ Percentage of inhibition } \\
\cline { 2 - 3 } & DPPH & NBT \\
\hline 10 & $11.5 \pm 2.1$ & $17 \pm 0.7$ \\
15 & $15.5 \pm 0.7$ & $21.6 \pm 3$ \\
25 & $18 \pm 1.4$ & $25.6 \pm 1.15$ \\
50 & 38 & $40.3 \pm 0.57$ \\
75 & $56 \pm 1.8$ & $44.6 \pm 2$ \\
100 & $78 \pm 1.4$ & $50.3 \pm 2.5$ \\
250 & $93.3 \pm 1.15$ & $56.6 \pm 1.5$ \\
500 & $96.6 \pm 0.57$ & $59.6 \pm 2.08$ \\
750 & $98.6 \pm 0.57$ & $64.6 \pm 1.15$ \\
1000 & 99 & $69.6 \pm 0.57$ \\
IC 50 value & $67.5 \pm 3.5$ & $95.5 \pm 6.3$ \\
\hline
\end{tabular}

DPPH: 2,2 Diphenyl 1- picrylhydrazyl, H. spinosa: Hygrophila spinosa

Table 12: Antioxidant property of $N$. zeylanica aerial part

\begin{tabular}{lll}
\hline $\begin{array}{l}\text { Concentration of plant } \\
\text { extract }(\boldsymbol{\mu g} / \mathrm{L})\end{array}$ & \multicolumn{2}{l}{ Percentage of inhibition } \\
\cline { 2 - 3 } & DPPH & NBT \\
\hline 10 & $3.6 \pm 0.51$ & $15.3 \pm 0.34$ \\
15 & $8.86 \pm 2.57$ & $24.58 \pm 0.29$ \\
25 & $12.1 \pm 1.9$ & $35.68 \pm 0.30$ \\
50 & $16.03 \pm 4.2$ & $44.12 \pm 0.45$ \\
75 & $21.63 \pm 2.6$ & $49.84 \pm 2.09$ \\
100 & $23.9 \pm 2.12$ & $52.84 \pm 1.13$ \\
250 & $38.5 \pm 1.49$ & $68.34 \pm 0.68$ \\
500 & $60.9 \pm 1.27$ & $77.41 \pm 0.29$ \\
750 & $79.77 \pm 2.18$ & $81.46 \pm 1.81$ \\
1000 & $93.71 \pm 1.39$ & $84.52 \pm 1.23$ \\
IC 50 value & $373 \pm 2.81$ & $74.66 \pm 8.5$ \\
\hline
\end{tabular}

DPPH: 2,2 diphenyl 1- picrylhydrazyl, N. zeylanica: Naravelia zeylanica

\section{Superoxide radical scavenging assay}

The superoxide radical scavenging assay also shows significant radical scavenging property with IC50 values $146.6 \pm 3.6,95.5 \pm 6.3$, and $74.66 \pm 8.5$, respectively, in $S$. suaveolens, $H$. spinosa, and $N$. zeylanica. The activity was increasing with the increasing concentrations of test solution and shows least IC50 value in N. zeylanica.

The present study indicates that the studied medicinal plant extracts could inhibit the oxygen radicals as seen from scavenging superoxide and DPPH radicals, and it could reduce the oxygen radicals and subsequently reduce the harmful effects. The literature supports that phytoconstituents such as polyphenolic compounds in drugs are responsible for the antioxidant potential [22,23]. Further, phenolic compounds are effective hydrogen donors, which make them antioxidant [24]. Leaves of S. suaveolens and H. spinosa and aerial parts of $N$. zeylanica possess valuable secondary metabolites such as phenols, flavonoids, alkaloids, and tannins $[3,25,26]$, the observed activity may be due to the presence of these phytoconstituents.

\section{CONCLUSION}

All the extracts showed varying degrees of antimicrobial, anthelmintic, and antioxidant properties. All these plants were more effective than the commercial antibiotics in combating the helminth studied. To combat pathogenic microorganisms, the folk medicines screened in this in vitro study can be used as effective agent due to the efficiency and less side effects. The luxuriant use of these medicinal plants in folk medicine proves that they represent a safe and economic alternative to treat various infectious diseases and oxidative stress damages.

\section{ACKNOWLEDGMENTS}

The authors are grateful to St. Mary's College Thrissur, Kerala, India, for the provision of laboratory facilities and to the traditional healers for sharing their valuable knowledge.

\section{AUTHORS' CONTRIBUTION}

Alby Alphons Baby has performed all the experiments in the laboratory. Regi Rahael $\mathrm{K}$ has provided the design, intellectual content to choose the plant, and act as a mentor for the works.

\section{CONFLICTS OF INTEREST}

The authors declare that they do not have any conflicts of interest.

\section{REFERENCES}

1. Beegam AR, Nayar TS. Plants used for natal health care in folk medicines of Kerala, India. Indian J Tradit Knowledge 2011;10:523-27.

2. Nastro A, Germano M, Marino DV, Cannatelli M. Extraction methods and bioautography for evaluation of medicinal plant antimicrobial activity. Lett Appl Microbiol 2000;30:379-84.

3. Meena K, Yadav AK, Panda P, Preet K, Rao MM. Review on Stereospermum suaveolens (Roxb.) DC; a potential herb. Drug Invent Today 2010;2:238-39.

4. Gamble JS. Flora of the Presidency of Madras. Dehradun: Bishen Singh and Mahendra Pal Singh; 1915.

5. Udayan PS, George S, Tushar KV, Balachandran I. Medicinal plants used by malayali tribes of Sevarayan hills Yercad, Salem district, Tamilnadu, India. Zoo Print J 2006;21:2223-4.

6. Anonymous. The Useful Plants of India. New Delhi: NISCAIR; 1992. p. 392.

7. Asolkar LV, Kakkar KK, Chakre OJ. Second Supplement to Glossary of Indian Medicinal Plants with Active Principles. New Delhi: NISCAIR, CSIR; 2005.

8. Khare CP. Indian Medicinal Plants: An Illustrated Dictionary. India: Springer Publications; 2007

9. Sharma PC, Yelne MB, Dennis TJ. Database on Medicinal Plants used in Ayurveda. Vol. 4. New Delhi: Central Council for Research in Ayurveda and Siddha; 2002.

10. Rastogi RP, Mehrotra BN. Compendium of Indian Medicinal Plants. Vol. 3. New Delhi: Publication and Information Directorate, CSIR; 1993.

11. Baby AA, Raphael KR. First step towards unravelling the medicinal properties of an endemic traditional medicine Bauhinia phoenicea Wight and Arn bark. Int J Pharm Pharm Sci 2015;7:403-5.

12. Rojas JJ, Ochoa VJ, Ocampo SA, Munoz JF. Screening for antimicrobial activity of ten medicinal plants used in Colombian folkloric medicine: A possible alternative in the treatment of nosocomial infections. BMC Complement Altern Med 2006;6:2.

13. du Toit EA, Rautenbach M. A sensitive standardized micro-gel well diffusion assay for the determination of antimicrobial activity. J Microbiol Methods 2000;42:159-65.

14. Vital PG, Velasco RN, Demigillo JM, Rivera WL. Antimicrobial activity, cytotoxicity and phytochemical screening of Ficus septica Burm and Sterculia foetida L leaf extracts. J Med Plant Res 2010;4:58-63.

15. Baby AA, Raphael KR. Potential antimicrobial, anthelmintic and antioxidant properties of Areca catechu L root. Int J Pharm Pharm Sci 2014;6:486-89.

16. Braca A, Sortino C, Politi M. Anti-oxidant activity of flavonoids from 
Licania licaniaeflora. J Ethnopharmacol 2002;79:379-81.

17. Deb L, Dubey SK, Jain A, Jain AK, Pandian GS. Preventive effect of Thuja occidentalis (Linn) on gastric ulcer-a novel role of free radical scavenger. J Nat Remedies 2009;9:152-8.

18. Andlauer W, Furst P. Antioxidative power of phytochemicals with special reference to cereals. Cereal Foods World 1998;43:356-9.

19. Jayaprakasha GK, Selvi T, Sakariah KK. Antibacterial and antioxidant activities of grape (Vitis vinifera) seed extract. Food Res Int 2003;36:117-22

20. Uttara B, Ajay VS, Zambi P, Mahajan RT. Oxidative stress and neurodegenerative disease; A review of upstream and downstream antioxidant therapeutic options. Curr Neuropharmacol 2009;7:65-74.

21. Koleva II, Van Beek TA, Linseen JP, de Groot A, Evstatieva LN. Screening of plant extracts for antioxidant activity: A comparative study on three testing methods. Phytochem Anal 2002;13:8-17.
22. Khushad MM, Masiunas MA, Smith W, Eastmank K. Health promoting phytochemicals invegetable. Hortic Rev 2003;28:125-85.

23. Gooijer CR, Evade H, Zappey H. Liquid chromatography with atmospheric pressure chemical ionization and electroscopy ionization mass spectroscopy of flavonoids with triplequadrupole and ion trap instruments. J Chromatogr 1997;984:45-8.

24. Rice-Evans CA, Miller NJ, Bolwell PG, Bramley PM, Pridham JB. The relative antioxidant activity of plant derived polyphenolic flavonoids. Free Radic Res 1995;22:375-83.

25. Sutharsingh R, Kavimani S, Jayakar B, Uvarani M, Thangathirupathi A. Quantitative phytochemical estimation and Antioxidant studies on aerial parts of Naravelia zeylanica DC. Int J Pharm Stud Res 2011;2:52-6.

26. Kshirsagar $\mathrm{AD}$, Ingale $\mathrm{KG}$, Vyawahare NS, Thorve VS. Hygrophila spinosa: A comprehensive review. Pharmacogn Rev 2010;4:167-71. 